\title{
Mitochondrial Uncoupling Protein 2 Hyperinsulinism
}

National Cancer Institute

\section{Source}

National Cancer Institute. Mitochondrial Uncoupling Protein 2 Hyperinsulinism. NCI

Thesaurus. Code C131838.

Hyperinsulinism due to mutation(s) in the gene UCP2, encoding mitochondrial uncoupling protein 2 , which plays a role in attenuating insulin secretion. 